\title{
BUILDING MOSQUE'S COMPETITIVE ADVANTAGE THROUGH THE MANAGEMENT OF IMAMS
}

\author{
M. Syukur Ifansyah ${ }^{1}$, Ahmad Faiz Khudlari Thoha ${ }^{2}$, Reka Gunawan ${ }^{3}$ \\ ${ }^{123}$ Da'wa Study Program, STIDKI Ar Rahmah Surabaya \\ 123 Syukurifansyah12@gmail.com
}

\begin{abstract}
Like business enterprises, mosques and other nonprofit organizations also need to have a vital source of competitive advantage to increase their worshippers' uniqueness and attractiveness. If it can be adequately managed, imam masjid can be one of the uniqueness and continuing excellence for the mosque. One of the best practices in managing mosque' imams as a competitive advantage is Masjid Raya Hubbul Wathan Islamic Center in West Nusa Tenggara. This research examines differentiation strategies in managing imams at Masjid Raya Hubbul Wathan Islamic Center in West Nusa Tenggara and how imams in the mosque can be a source of sustainable excellence and not only temporary. This research was conducted using qualitative methods with a case study approach. The collected data is analyzed descriptively based on the theory of competitive advantage, differentiation, and the VRIO framework. Among the critical findings in this study is the differentiation strategy in the management of imams at Masjid Raya Hubbul Wathan Islamic Center in West Nusa Tenggara carried out by: (1) the existence of a measurable and selective imam recruitment process; (2) the availability of competent priests with extensive and varied numbers; (3) involvement of international priests; and (4) the existence of a system of appreciation, improvement, empowerment of good mosque imams.
\end{abstract}

Keywords: Imam of Mosque, Competitive Advantage, Differentiation, Mosque Management

Abstrak: Sebagaimana perusahaan bisnis, masjid dan organisasi nirlaba lainnya juga perlu memiliki sumber keunggulan kompetitif yang kuat dalam rangka meningkatkan keunikan dan daya tarik jamaahnya. Jika mampu dikelola dengan baik, Imam Masjid dapat menjadi salah satu keunikan dan keunggulan yang berkelanjutan bagi masjid. Salah satu praktek terbaik dalam pengelolaan imam masjid sebagai keunggulan kompetitif dapat ditemukan pada Masjid Raya Hubbul Wathan Islamic Center Nusa Tenggara Barat. Penelitian ini bertujuan untuk mengkaji strategi diferensiasi dalam pengelolaan imam di Masjid Raya Hubbul Wathan Islamic Center Nusa Tenggara Barat serta bagaimana imam di masjid tersebut dapat menjadi sumber keunggulan yang berkelanjutan dan tidak hanya bersifat sementara. Penelitian ini dilakukan dengan menggunakan metode kualitatif dengan pendekatan studi kasus. Data yang terkumpul dianalisis secara deskriptif berdasarkan teori keunggulan kompetitif, diferensiasi, dan kerangka VRIO. Di antara temuan penting dalam penelitian ini adalah strategi diferensiasi dalam pengelolaan imam di Masjid Raya Hubbul Wathan Islamic Center Nusa Tenggara Barat dilakukan dengan: (1) adanya proses rekrutmen imam yang terukur dan selektif; (2) ketersediaan imam yang kompeten dengan jumlah yang besar dan variatif; (3) pelibatan imam internasional; serta (4) adanya sistem apreasiasi, pembinaan, pemberdayaan imam masjid yang baik.

Kata Kunci: Imam Masjid, Keunggulan Kompetitif, Diferensisasi, Manajemen Masjid 


\section{A. Introduction}

Indonesia is the country with the largest Muslim population in the world. Based on the Central Statistics Agency data, the number of Muslims in Indonesia in 2010 reached 209.12 million people or about $87 \%$. Even in 2020, the number of people in Indonesia increased drastically to reach 270.20 million people. West Nusa Tenggara is one of the provinces with diverse cultural and language patterns. The province, located in the western part of the Nusa Tenggara archipelago, consists of eight districts and two cities with 5,070,385 people. The majority of the population in this province embraces Islam. Even the percentage of Muslims in West Nusa Tenggara reached $96.78 \%$ of the total number of people in the community. 12

Lombok, one of the islands located in West Nusa Tenggara, received the title of the island of a thousand mosques given by the Director-General of Bimas Islam Ministry of Religious Affairs, Effendi Zarkasih, in 1970 when visiting the island of Lombok to inaugurate the Cakranegara mosque. The title of the island of a thousand mosques is motivated because Effendi Zurkasih was impressed with the number of mosques in Lombok.

Besides being known as Pulau Seribu Masjid, Lombok island is also known for its diverse and beautiful tourist destinations. Many amazing beauties can be enjoyed on this island, such as beaches, waterfalls, mountains, historical tours, pilgrimage tours, and cultural tours. In 2019 Lombok was named the world's best halal tourist destination according to the Global Muslim Travel Index (GMTI) 2019 by rating agency Mastercard-Crescent Rating. ${ }^{3}$

Seeing the opportunity owned by Lombok Island, some mosques are not only functioned as places of worship will still be one of the halal tourist destinations, one of which is Masjid Raya Hubbul Wathan Islamic Center. As the mosque in general in Masjid Raya Hubbul Wathan Islamic Center Jama'ah prayer service is the leading service for the mosque, namely by providing an area of 3.6 hectares as the main building and presenting the best imams from NTB.

Masjid Raya Hubbul Wathan Islamic Center provides fourteen permanent imams for congregational prayer activities every day. Regarding improving the service and appeal for jama'ah, the Masjid Raya Hubbul Wathan Islamic Center made a policy by categorizing imams out of fourteen remaining imams. Thus, seven imams are hafidz of the Qur'an as imams at the time of jahr (prayer with hardened recitation), while the other seven are from among elders who are called Tuan Guru and Dewan Hakam for sirr prayers.

Masjid Raya Hubbul Wathan Islamic Center routinely invites foreign imams from the Middle East as tarawih imams and qiyamul lail prayers in Ramadan. Thus, the mosque is always filled with jama'ah -jama'ah from various districts from the beginning to Ramadan. Even towards the end of Ramadan, many jama'ah are willing to sleep in the mosque to I'tikafand follow qiyamul lail activities.

By categorizing and trying to bring imams from the Middle East, this is one form of promotion of mosques to all Muslims in various regions, including those outside the island of Lombok. So that the hope in the future, Masjid Raya Hubbul Wathan Islamic Center becomes more prosperous and much visited by Muslims from any region. Moreover, many worshippers who attend prayers at Masjid Raya Hubbul Wathan Islamic Centerwill build the mosque's competitive advantage. Thus, the mosque has been recognized by the community for the quality of its service.

Imam of Masjid Raya Hubbul Wathan Islamic Center is one of the mosque's priorities by strict recruitment. The Imam's criteria that must be met in this mosque is hafidz thirty juz and get

\footnotetext{
1 Official News Statistics Results Sesnsus Penduduk, 2020, p. p. 3 $<$ https://doi.org/10.1093/bioinformatics/btt053>.

2 'Central Bureau of Statistics of West Nusa Tenggara Province' <https://ntb.bps.go.id/statictable/2017/11/15/189/persentase-penduduk-menurut-kabupaten-kotadan-agama-yang-dianut-di-provinsi-nusa-tenggara-barat-2016.html> [accessed 23 July 2021].

3 'Lombok Selected As The Best Halal Tourist Destination In Indonesia - ANTARA News' <https://www.antaranews.com/berita/821961/lombok-terpilih-sebagai-destinasi-wisata-halal-terbaikdi-indonesia> [accessed September 25, 2020].
} 
Vol. 3 No. 1, 2021

recommendations from pesantren. The elected imams will follow the tahsin activities every Wednesday night and be guided on the fiqh of imamah and Qiro'ah sab'ah as the breadth of tsaqofah.

Joe Saxton said that a competitive advantage for nonprofit organizations could be achieved by maintaining attractive and different services. Michael E. Porter also corroborates this in his book entitled "Competitive Advantage Creating and sustaining superior performance," saying that every organization is essential to have a competitive advantage because it is at the heart of organizational performance in the competitive market. ${ }^{5}$

Research on competitive advantage has been done a lot before. First, the 2019 Thesis written by Elly Kartika Sari entitled "Strategic Management in building competitive advantage (Competitive Advantage) of public/private Islamic religious colleges in Samarinda." ${ }^{6}$ Second, a 2004 journal written by Sri Harjanti entitled "Creating a Sustainable Competitive Advantage Through Human Resource Management." ${ }^{7}$ Third, the thesis was written by Ayu Wiji Lestari with the title "Creating Competitive Advantage Through The Level of Interest and Service Performance at Lumintu 1001 Fishing Restaurant in Janti Village klaten regency".8

All previous research has addressed the competitive advantages of profit organizations. The first research discusses strategic formulations in building competitive advantage and how to make strategic implementation in building competitive advantage. The second research discusses future HR management and development strategies to create a sustainable competitive advantage, through the third MSDM discussing plans to build competitive advantage in food restaurants.

Instead of the research above, Thoha and $\mathrm{Al} \mathrm{Mufti}{ }^{9}$ studied the implementation of strategic management in nonprofit educational institution which pointed the importance of strategic plan for nonprofit organization. Meanwhile, after looking at some examples of the above research, researchers concluded that research on competitive advantages around nonprofit organizations is rarely found, especially mosques. Therefore, this research will be beneficial to increase references about competitive advantage in nonprofit organizations.

\section{B. Theoretical Review}

1. Competitive Strategy

Michael E. Porter says that competitive advantage is the life, soul, or heart of the performance of a business, which is competitive in its efforts to further develop, especially in the diversification of a product. In another definition, Robert M. Grant mentions that competitive advantage is the advantage of an organization obtained from the competitive capabilities among other organizations.

Every competitive organization within the industry certainly wants its organization to be far superior to other organizations. In response to this, generally, the organization will make policies so that they can be achieved. Building a competitive advantage through resources as the

\footnotetext{
4 Joe Saxton, 'Strategies for Competitive Advantage in Nonprofit Organisations', International Journal of Nonprofit and Voluntary Sector Marketing, $1.1 \quad$ (1996), $\quad$ p. p. 51 <https://doi.org/10.1002/nvsm.6090010108>.

${ }^{5}$ Michael E. Porter, 'Competitive Advantage Creating and Sustaining Superior Performance', Studia Politica (New York, 2018), p. hlm 68.

6 Suci Wahyuni Arti, 'Analisis Strategi Keunggulan Bersaing Produk Salon Syariah D'mutia Spa Dan Muslimah Di Semarang Dalam Upaya Meningkatkan Jumlah Pelanggan' (Universitas Negeri Islam Wali Song, 2019), p. hlm 1-154.

7 Sri Harjanti, 'Menciptakan Keunggulan Bersaing Yang Berkelanjutan Melalui Manajemen Sumber Daya Manusia', Jurnal Ekonomi Dan Kewirausahaan No. 1, Vol. (2004), 41-57.

${ }^{8}$ Ayu Wiji Lestari, 'Creating Competitive Advantage Through The Level of Interest and Service Performance at Lumintu 1001 Fishing Restaurant in Janti Village klaten Regency', 2018, thing 28.

${ }_{9}^{9}$ Ahmad Faiz Khudlari Thoha, 'Implementasi Strategi Pemasaran Dalam Meningkatkan Daya Tarik Program Masjid ( Studi Kasus Masjid Ar-Rahmah Surabaya)', Masjiduna : Junal Ilmiah Stidki Ar-Rahmah, 3.2 (2020), 93 <https://doi.org/10.52833/masjiduna.v3i2.66>.
} 
most significant contributor to the organization is the right strategy to increase customers by providing more value than competitors.

Competitive strategy is a means to achieve advantages that have been targeted, including competitive advantages. Strategy is essentially an art and science that uses and develops forces (ideology, political, economic, socio-cultural) to achieve previously targeted goals. So that competitive strategy can be interpreted as planning to conduct the competition and make policies to achieve these goals. The most commonly used competitive strategy as a reference is the one put forward by Porter (1980). Porters Generics Competitive Strategies is a strategy that companies use to achieve competitive advantage. This strategy is divided into three approaches:

a. Cost Leadership Strategy

It is an effort to gain a competitive advantage by increasing sales through the lowest price offer. This strategy is very suitable to be applied to price-sensitive consumption. Because they are willing to get a more inferior quality product because of the focus at a lower price, a lowcost strategy will make the organization earn above-average profits despite the strength of competition due to its low cost.

b. Differentiation Strategy

It is a strategy to accelerate competitive advantage by presenting products that are different and superior to others. The application of this strategy depends on the natural conditions of the industry, product, or service itself.

c. Focus Strategy

It is a strategy to gain a competitive advantage by applying the previous two methods, not the general market segment. Instead, this strategy is used for smaller and specific market segments. The key to ensuring the success of this strategy is to add extra value from the results of service to these small and specific market segments. In an analysis conducted by researchers, Masjid Raya Hubbul Wathan Islamic Center applied differentiation strategies to maximize imams' potential and use VRIO theory to maintain the sustainability of competitive advantage.

\section{Resource-Based View}

Resource-Based View is a concept developed by Jay Barney in 1991. Jay Barney's vision made a significant contribution to strategic management as it provided new enlightenment to the study of leadership. The perspective of the industrial organization previously dominated it. Industrial organizations consider that industrial (external) forces will largely determine the performance of the organization. However, the concept of Resource-Based View, on the contrary, believes that competitive advantage is achieved through resources (internal) forces. ${ }^{1011}$

The resource-based view concept can answer phenomena that the idea of industrial organization cannot answer. An organisation's problem in an industry has a different performance and different levels of effectiveness and efficiency. An organization must also have resources that have no substitute. Although an organization has valuable, unique, and complex help, competitors have an equivalent replacement, and they are no longer a sustainable competitive advantage. Thus, heterogeneous resources that do not have high mobility will determine the resources worth, rare, difficult to replicate, and challenging to find a replacement. ${ }^{12}$

\section{VRIO Concept}

Every organization that has conducted a competition in the industry must maintain the advantages that have been obtained. Therefore, the framework used to achieve sustainable

\footnotetext{
10 Jay Barney, 'Firm Resources and Sustained Competitive Advantage', Journal of Management, 17.1 (1991), 99-122 (p. hal 101) <https://doi.org/10.1177/014920639101700108>.

11 Ratno Purnomo, 'Resource-Based View Dan Keunggulan Bersaing Berkelanjutan : Sebuah Telaah Kritis Terhadap Pemikiran Jay Barney ( 1991 )' (Universitas Jenderal Soedirman, 1999), p. hal 2.

12 Purnomo, p. p. p7.
} 
competitive advantage is to carry out strategies that optimize internal strengths through exploiting opportunities in the external environment, neutralizing threats from the external environment and minimizing the internal weaknesses of the organization.

An organization will gain a competitive advantage through optimizing the potential of resources that maximize the organization's internal strengths and analyze its weaknesses. Resources are said to be valuable when used to implement strategies that have been built by the organization. Meanwhile, organizations are said to be rare when the resources owned are not owned by other organizations. So, the organization can make the most of the potential possessed by the resources owned while other organizations cannot imitate it.

Barney elaborates that four things can be used as an indicator to find out whether the resources owned by an organization can be used as a sustainable competitive advantage in between is

1) Value of Resource Utilization (Valuable);

2) Rare Resources (Rare);

3) Resources that are difficult to imitate (Inimitable);

4) Optimization of the role of resources (Organization) ${ }^{13}$

\section{Methods}

In this study, researchers used qualitative methods to explore and understand the meanings that several individuals or groups perceive as derived from social or humanitarian problems. The five approaches described by Cresswell are Biography, Phenomenology, Grounded-theory, Ethnography, and Case Studies. In this case, researchers use a case study approach that aims to explore a particular issue in more depth by collecting various sources of information. ${ }^{14}$

The data source in this study was obtained from interviews with mosque administrators, worshippers, and the Imam of the Masjid Raya Hubbul Wathan Islamic Center. Other data sources were obtained through direct observation to the research site and additional data from documents, websites, and social media accounts owned by Takmir Masjid Hubbul Wathan Islamic Center Mataram, such as YouTube and Facebook, and Instagram.

\section{Results And Discussions}

The mosque's Imam is a leader used as a role model and follows every movement and deeds and readings in prayer. But, in a broader sense, the Imam is someone who is followed every trace of his who carries out the duty of Allah Azza Wa Jalla to call on Allah Azza Wa Jalla and warn people to perform prayers and perform zakat.

Choosing a priest must be in line with what Allah has taught his Messenger. Several criteria must be considered in terms of selecting a priest.

1) He remembers the Qur'an the most and understands it.

2) People who know the most about sunnah

3) The one who first migrated

4) First, convert to Islam.

The four criteria mentioned above are the priority standards that must be met first. Therefore, the four criteria above are not an option but must be chosen based on the priority of the first to the fourth criterion.

Hubbul Wathan Islamic Center is a mosque located on the island of Lombok NTB. This mosque is visited by many jama'ah and visitors from outside the island because it has an attractive infrastructure and is an icon of the island of a thousand mosques. As an icon representing the mosque in NTB, Masjid Raya Hubbul Wathan Islamic Centre is equipped with quality facilities, in

\footnotetext{
13 Barney.

${ }^{14}$ John W Creswell, Research Design: Qualitative, Quantitative, and Mixed Methods Approaches, Forth Edit (Washington DC: SAGE Publications, Inc., 2014), p. hlm 21.
} 
addition to the congregational prayer service as the primary function of the mosque is also managed very well, namely by presenting imams who hafidz Al-Qur'an and also from various community leaders.

Regarding jama'ah prayer services, Masjid Raya Hubbul Wathan Islamic Center Mataram has 14 permanent imams and a categorization of imams. That is seven imams of jahr prayer (hardened prayer) and the following seven imams as imams of sirr prayer (prayers that are not set). In addition, Masjid Raya Hubbul Wathan Islamic Center routinely brings imams from the Middle East during Ramadan. This aims to raise the spirit of jama'ah so that it is always istiqomah to perform tarawih prayers and other worships. With this service, this mosque is even more crowded towards the end of Ramadan, where most mosques are increasingly quiet.

Among the critical findings in this study is the differentiation strategy in the management of imams at Masjid Raya Hubbul Wathan Islamic Center in West Nusa Tenggara is carried out by (1) the existence of a measurable and selective imam recruitment process; (2) the availability of competent priests with extensive and varied numbers; (3) involvement of international priests; and (4) the existence of a system of appreciation, construction, empowerment of good mosque imams. (5) This mosque's ability to recruit several international qari' and community religious figures from various backgrounds is the most challenging source of continuous excellence to imitate so that the mosque has solid social recognition. These five essential points will be discussed in detail in the following discussion.

\section{Differentiation Strategy in Resource-Based View Aspects}

Differentiation strategy is one of the strategies of an organization to provide a unique product or service to its customers. Saxton mentioned that differentiation strategies are the most likely strategies for organizations to gain a competitive advantage. 15

According to porter, there are nine aspects of uniqueness that become differentiation for an organization, namely;

1. Product features and product performance; Product features and service performance.

2. Complementary services; Additional services

3. Intensity of marketing activities; Intensity of market activity

4. Technology embodied in design and manufacture; Technology, design, and manufacturing

5. The quality of purchased inputs; Quality of purchased inputs

6. Procedures influencing the conduct of each of the activities; Procedures for the implementation of each activity

7. The skill and experience of employees; Skills and experience of employees

8. Location; Location

9. The degree of vertical integration; Resources that can control activities ${ }^{16}$

Among some of the aspects mentioned by Porter above, researchers found six factors that have been applied by Masjid Raya Hubbul Wathan Islamic Center as uniqueness and differentiation in the management of imams. Among them are: Recruitment (the quality of purchased inputs), quantity and composition (skill and experience of employees), infrastructure facilities(technology), ordinary day performance and memorable moments (product performance), appreciation, coaching, and empowerment (complimentary services), social media (intensity of marketing).

\footnotetext{
15 Saxton.

${ }^{16}$ Michael E. Porter, p. hal 124.
} 
Table 1.1 Six factors have been applied in the management of imams.

\begin{tabular}{|c|c|c|c|}
\hline No & Porter's Theory & Result & Finding \\
\hline 1 & $\begin{array}{l}\text { The Quality of } \\
\text { Purchased } \\
\text { Inputs }\end{array}$ & Recruitment Aspects & $\begin{array}{l}\text { 1. Selecting the criteria of the Imam } \\
\text { 2. Making priestly selection }\end{array}$ \\
\hline 2 & $\begin{array}{lr}\text { Skill } & \text { and } \\
\text { experience } & \text { of } \\
\text { employees } & \end{array}$ & $\begin{array}{l}\text { Aspects of Quantity } \\
\text { and Composition }\end{array}$ & $\begin{array}{l}\text { Have fourteen remaining imams, seven are } \\
\text { imams who hafidz the Qur'an and seven are } \\
\text { from among the elders and master teachers }\end{array}$ \\
\hline 3 & Technology & $\begin{array}{l}\text { Aspects of Facilities } \\
\text { and Infrastructure }\end{array}$ & $\begin{array}{l}\text { bisyarah, microphone, teaching, thick } \\
\text { carpets, air-conditioned rooms, and } \\
\text { Soundsystem are very influential on the } \\
\text { comfort of congregational prayers. }\end{array}$ \\
\hline 4 & $\begin{array}{l}\text { Product } \\
\text { Performance }\end{array}$ & $\begin{array}{l}\text { Aspects of Ordinary } \\
\text { Day Performance and } \\
\text { Special Moment }\end{array}$ & $\begin{array}{l}\text { 1. Imam schedule, the existence of badal, } \\
\text { maqro' imam readings are sustainable. } \\
\text { 2. Brings imams from the Middle East to } \\
\text { lead prayers during Ramadhan }\end{array}$ \\
\hline 5 & $\begin{array}{l}\text { Complementary } \\
\text { Services }\end{array}$ & $\begin{array}{l}\text { Appreciation, } \\
\text { Coaching } \\
\text { Empowerment } \\
\text { Priests }\end{array}$ & $\begin{array}{l}\text { 1. For the imams of the mosque's } \\
\text { honorarium, the it is still the } 300,000 \text {. } \\
\text { 2. Imams who come from the Middle East } \\
\text { during Ramadan reaching } 6000-7000 \text { US } \\
\text { Dollars } \\
\text { 3. Foster and empower the potential of } \\
\text { imams, such as means to teach }\end{array}$ \\
\hline 6 & $\begin{array}{l}\text { Intensity of } \\
\text { Marketing Act }\end{array}$ & Social Media & $\begin{array}{l}\text { Hubbul Wathan Islamic Center is recording } \\
\text { when the activities of jama'ah prayer occur }\end{array}$ \\
\hline
\end{tabular}

\section{Analysis of Imam's Competitive Sustainability Based on VRIO Concept}

In the observations and interview results of researchers, the four theories mentioned by Barney above follow what researchers get in the field, namely:

a. Value of Imam's Usefulness (Valuable)

Valuable resources are resources that can provide strategic advantages for organizations and can help organizations in utilizing market opportunities. The greater the value provided by the resources of an organization, the more valuable the resource. Among the giant forms of benefit presented by the Imam of Masjid Raya Hubbul Wathan Islamic Center are:

1) The growing number of pilgrims

One of the factors that make many worshippers present to perform congregational prayers at Masjid Raya Hubbul Wathan Islamic Centeris to present qualified imams. Especially in the month of Ramadan, imams are delivered from the Middle East to give a new Susana in performing the congregational prayer so that thousands of jama'ah come in droves to the mosque. This is due to the stigma of the community that captures that imam from abroad, such as the Middle East, seem to be a unique attraction for people to come to pray in this mosque. Even the end of Ramadan is not the less it gets.

2) Building a solid social base of mosques

The mosque's strong social base is one of the values built in Masjid Raya Hubbul Wathan Islamic Center by involving figures from the Tuan Guru, Dewan Hakam, and as popular as there are. Imams from among figures such as Tuan Guru, Dewan Hakam, and Elders are rarely found in other mosques, especially The Master Teachers, who come from different backgrounds. Masjid Raya Hubbul Wathan Islamic Center can interact from any circle. This will undoubtedly strengthen the social base of the mosque because it is accepted and recognized by the surrounding community.

3) Building synergy between mosques and the government and boarding schools 
Building synergy between mosques with the government and boarding schools is one of the values created by involving Bureaucrats, the Ministry of Trade, and pesantren regarding recruitment and recommendations of outstanding students. The government's involvement in the recruitment of imams is one way for mosques to build and strengthen the synergy between mosques and the government. The mosque also creates synergy with pesantren huts in Lombok by making children graduates of houses who are following the recommendations to become imams in this mosque.

b. Rare Values in Imam's Pegelolaan (Rare)

One of the aspects that make an organization superior in terms of the competition is its resources that are difficult to imitate by other organizations. Among the aspects that are difficult to imitate in terms of the management of the Imam of Masjid Raya Hubbul Wathan Islamic Center are:

1) Quantity and composition of priests

One form of usefulness presented in the management of the Imam of Masjid Raya Hubbul Wathan Islamic Center is to categorize the Imam of fourteen numbers permanent imams, seven of whom are imams who hafidz the Qur'an for Maghrib and Isha' prayers and seven others from among elders and master teachers for Dzuhur and Ashar prayers. Among the fourteen priests, especially for priests at dawn directly filled by the speaker of the study ba'da dawn. Unless indeed the speakers who are not good at reading the Qur'an, then it has been provided imam badal.

2) Priest performance

Among the forms of efforts of Masjid Raya Hubbul Wathan Islamic Center in providing the best service to jama'ah is by optimizing the performance of the Imam. As with scheduling, the system reads sequences and badal imams.

c. Aspects that cannot be imitated in the management of priests (Inimitable)

Rare values and characteristics in resources will provide standard and short-term benefits. When other organizations can emulate these characteristics, they cannot offer any more extended benefits. Therefore, an organization must-have element that are rare and not easily imitated by other organizations.

A rare and not easily imitated aspect of managing imams at Masjid Raya Hubbul Wathan Islamic Center is choosing and appointing imams from among figures such as elders, hakam councils, and teacher figures. By involving these figures as priests. It will indirectly strengthen the social base of the mosque. So that the relationship of the mosque with the community and the cottage is also getting stronger. This is a form of synergy that creates unity by becoming the centre of the gathering of essential figures on the island of Lombok.

Priests from among these figures are presented from various circles with different backgrounds. Masjid Raya Hubbul Wathan Islamic Center became one of the mosques as a container for gathering these figures. Where not infrequently in some mosques, the figures sometimes have conflicts because of differences of opinion. Moreover, the Imam of the Master's circle at the Hubbul Wathan Grand Mosque is not a few, but seven people for zuhur and ashar prayers and dozens of Master Teachers for imams at dawn prayers.

So, of course, there are many thoughts ikhtilaf among these figures. However, Masjid Raya Hubbul Wathan Islamic Centeris present as one of the gatherings of figures on the island of Lombok. Not only functioning as imams, but the leaders of Tuan Guru also presented at Masjid Raya Hubbul Wathan Islamic Center to fill the study of ba'da maghrib and Fajr. As for the dawn prayer, usually, Tuan Guru, who is present, serves as an imam and a speaker of studies.

d. Optimization of imams management(organization)

Strategic resource management practices require effectively coordinated management. Because with effective leadership, the results of products or services provided by an organization can be maximized.

Among the forms of management of Masjid Raya Hubbul Wathan Islamic Centerto maximize the potential of imams to increase the number of jama'ah are: 
1) Efforts to publicize the priest's performance on social media

This is a strategic step to further introduce Masjid Raya Hubbul Wathan Islamic Center through the competence of imams by way of publication on the mosque's social accounts. Each prayer activity will be recorded by the mosque's media team and published on the mosque's social accounts such as YouTube and Facebook. To see the results that have been published videos, pilgrims can later see on the YouTube account hubbul wathan Tv or through the Islamic center NTB Facebook account.

2) Efforts to use the competence of diverse priests

The competence of other imams utilized by Masjid Raya Hubbul Wathan Islamic Center is science. The potential of the Imam to improve the integrity of the jama'ah by giving ta'lim is realized by conducting studies in the field of the Qur'an and other areas. So, jama'ah not only comes to perform jama'ah prayer but also to study.

By utilizing the potential and reputation of the Imam of The Grand Mosque, Hubbul Wathan Islamic Center Mataram is a value to build competitive advantage by maximizing effectiveness in the management of mosque imams. In addition, sound resource management systems and practices will be a potential source in improving organizational performance. 17

3) Efforts to create priestly comfort

To provide comfort, the Hubbul Wathan Islamic Center mosque provides facilities for imams. Among them is the Sound System with a price of billions that helps beautify the sound of priests, thick carpets, air-conditioned rooms and other facilities. The facilities provided by the mosque is one aspect that will encourage maximum performance, as stated by the source above.

4) Efforts to improve the quality of priests

To ensure all programs run smoothly and correct deficiencies in terms of service. Hubbul Wathan Islamic Center held an evaluation meeting with all imams and the entire ranks of the mosque. By keeping an evaluation meeting, is a form of mosque attention to jama'ah prayer services. Either service to jama'ah or service to the Imam of the mosque.

5) Mosque branding efforts through imam management

Imam of The Great Mosque Hubbul Wathan is better-known jama'ah with imams who have memorized Al-Qur'an, have a melodious voice and are experts in reciting Al Qur'an. So, the priests have indeed been strictly selected so that the elected are the qualified chosen priests.

For the month of Ramadan, imams are presented from the Middle East to give a different Susana. With the presence of imams from the Middle East, many jama'ah from outside the city of Mataram visited to perform tarawih prayers in this mosque.

\section{E. Conclusion}

Among the critical findings in this study is the differentiation strategy in the management of imams at Masjid Raya Hubbul Wathan Islamic Center in West Nusa Tenggara carried out by: (a) the existence of a measurable and selective imam recruitment process; (b) the availability of competent priests with extensive and varied numbers; (c) involvement of international priests; and (d) the existence of a system of appreciation, construction, empowerment of good mosque imams. (e) This mosque's ability to recruit several qari' of international standard and community religious figures from various backgrounds is the most challenging source of continuous excellence to imitate. The mosque has solid social recognition. In several studies, there has been a lot of discussion about competitive advantage for-profit organizations. However, research on competitive advantages around nonprofit organizations is rarely found, especially mosques.

\footnotetext{
${ }^{17}$ Kasmawati. 
Therefore, the results of this study will be beneficial as a reference in improving the quality of imam management in other pilot mosques.

\section{Reference}

Arti, Suci Wahyuni, 'Analisis Strategi Keunggulan Bersaing Produk Salon Syariah D'mutia Spa Dan Muslimah Di Semarang Dalam Upaya Meningkatkan Jumlah Pelanggan' (Universitas Negeri Islam Wali Song, 2019)

'Badan Pusat Statistik Provinsi Nusa Tenggara Barat' <https://ntb.bps.go.id/statictable/2017/11/15/189/persentase-penduduk-menurutkabupaten-kota-dan-agama-yang-dianut-di-provinsi-nusa-tenggara-barat-2016.html> [accessed 23 July 2021]

Barney, Jay, 'Firm Resources and Sustained Competitive Advantage', Journal of Management, 17.1 (1991), 99-122 <https://doi.org/10.1177/014920639101700108>

$\begin{array}{lllll}\text { Berita Resmi Statistik Hasil Sesnsus } & \text { Penduduk, }\end{array}$ <https://doi.org/10.1093/bioinformatics/btt053>

Creswell, John W, Research Design : Qualitative, Quantitative, and Mixed Methods Approaches, Forth Edit (Washington DC: SAGE Publications, Inc., 2014)

Harjanti, Sri, 'Menciptakan Keunggulan Bersaing Yang Berkelanjutan Melalui Manajemen Sumber Daya Manusia', Jurnal Ekonomi Dan Kewirausahaan No. 1, Vol. (2004), 41-57

Kasmawati, Kasmawati, 'Sumber Daya Manusia Sebagai Sumber Keunggulan Kompetitif', Idaarah: $\begin{array}{lllll}\text { Jurnal Manajemen } & \text { Pendidikan, } & 2.2 & \text { (2018), }\end{array}$ <https://doi.org/10.24252/idaarah.v2i2.6864>

Lestari, Ayu Wiji, 'Meciptakan Keunggulan Bersaing Melalui Tingkat Kepentingan Dan Kinerja Pelayanan Pada Rumah Makan Pemancingan Lumintu 1001 Di Desa Janti Kabupaten Klaten', 2018, 28

'Lombok Terpilih Sebagai Destinasi Wisata Halal Terbaik Di Indonesia - ANTARA News' <https://www.antaranews.com/berita/821961/lombok-terpilih-sebagai-destinasi-wisatahalal-terbaik-di-indonesia> [accessed 25 September 2020]

Michael E. Porter, 'Competitive Advantage Creating and Sustaining Superior Performance', Studia Politica (New York, 2018)

Purnomo, Ratno, 'Resource-Based View Dan Keunggulan Bersaing Berkelanjutan : Sebuah Telaah Kritis Terhadap Pemikiran Jay Barney ( 1991 )’ (Universitas Jenderal Soedirman, 1999)

Saxton, Joe, 'Strategies for Competitive Advantage in Nonprofit Organisations', International Journal of Nonprofit and Voluntary Sector Marketing, 1.1 (1996) <https://doi.org/10.1002/nvsm.6090010108>

Thoha, Ahmad Faiz Khudlari, 'Implementasi Strategi Pemasaran Dalam Meningkatkan Daya Tarik Program Masjid ( Studi Kasus Masjid Ar-Rahmah Surabaya)', Masjiduna : Junal Ilmiah Stidki Ar-Rahmah, 3.2 (2020), 93 <https://doi.org/10.52833/masjiduna.v3i2.66> 